\title{
OCUPAÇÕES DE TERRA NO BRASIL (1988-2010): UMA LEITURA GEOGRÁFICA E A CONJUNTURA POLÍTICA DA LUTA PELA TERRA
}

\author{
José Sobreiro Filho \\ Estudante de Mestrado em Geografia \\ Universidade Estadual Paulista - Campus de Presidente Prudente (Brasil) \\ Correio Eletrônico: sobreirounesp@gmail.com.br
}

Recibido: 2 de agosto de 2011. Devuelto para revisión: 10 de agosto de 2011. Aceptado: 2 de septiembre de 2011

\begin{abstract}
RESUMO
Este trabalho se consiste em uma análise das ocupações de terra realizadas pelos movimentos sociais camponeses e a conjuntura política da luta pela terra no Brasil durante o período de 1988-2010. No Brasil, as ocupações de terra tem sido, ao longo dos anos, a principal forma de combater a desigualdade e a miséria causada pelo avanço do capitalismo no campo e promover o acesso à terra. Deste modo, os movimentos sociais camponeses se utilizam das ocupações estrategicamente para enfrentar o governo, combater a propriedade privada e lutar pela realização da reforma agrária de acordo com os seus interesses. Este processo político de luta entre interesses divergentes cria uma conflitualidade entre modelos diferenciados de desenvolvimento territorial rural e de organização sócio-política. Ademais, emergido pelo intenso avanço do agronegócio e interesses políticos, novos elementos tem surgido no campo brasileiro e re-dinamizado a luta pela terra. Os desdobramentos destes processos têm criado formas diferenciadas de luta pela terra, integração ao mercado, reprodução social e desenvolvimento territorial.
\end{abstract}

Palavras-Chave: Ocupações de terra, Luta pela terra, Conflitualidade, Movimentos socioterritoriais, Território.

\section{RESUMEN}

Este trabajo consiste en la interpretación de las ocupaciones de tierra realizadas por los movimientos sociales campesinos y la coyuntura política de la lucha por la tierra en Brasil, durante el periodo de 1988 a 2010. En Brasil las ocupaciones de tierra, a lo largo de los años, han sido la forma principal de, por un lado, combatir la desigualdad y la miseria causada por el avance del capitalismo en el campo y, por otro, promover el acceso a la tierra rural. De este modo, los movimientos sociales campesinos utilizan las ocupaciones estratégicamente para enfrentar al gobierno, combatir la propiedad privada y luchar por la realización de la reforma agraria de acuerdo con sus intereses. Este proceso político de lucha entre intereses divergentes crea conflictos entre modelos disímiles de desarrollo territorial rural y de organización sociopolítica. Además, como resultado del intenso avance de lo agronegocio e intereses políticos, aparecen nuevos elementos en el campo brasileño que redinamizan la lucha por la tierra. La aparición de estos procesos ha creado formas diferenciadas de lucha por la tierra, integración al mercado, reproducción social y desarrollo territorial. 
Palabras-Clave: ocupaciones de tierra, lucha por la tierra, conflictualidad, movimientos socioterritoriales, territorio.

\begin{abstract}
This works consists of an analysis of the land occupations realized by peasant social movements and the political struggle for land in Brazil from 1988 until 2010. In Brazil. the land occupations have been, over the years, the principal form of combating inequality and misery caused by the advance of capitalism in the countryside and of promoting access to land. In this sense, peasant social movements utilize the occupations strategically to confront the government, combat private property and struggle for the realization of agrarian reform in line with their interests. This process of political struggle between diverging interests creates a conflict between differentiated models of territorial rural development and the socio-political organization. Additionally, emerging from the intense advancement of agribusiness and political interests, new elements have arisen in the Brazilian countryside have re-energized the struggle for land. The consequences of these process have created differentiated forms of the struggle for land, the integration of the market, social reproduction and territorial development.
\end{abstract}

Key words: Land occupations, the Struggle for Land, Conflicts, Socio-territorial Movements, Territory

\title{
INTRODUÇÃO
}

Este artigo se consiste em um ensaio teórico acerca da conflitualidade na luta pela terra brasileira tendo como foco as variações nas ocupações de terra durante o período de 1988-2010. Minha principal motivação para realizar esta reflexão partiu da dificuldade que se encontrava em entender o conceito de território na geografia agrária sem considerar a conflitualidade, a luta de classes, a correlação de forças, etc. Durante as leituras que me permitiram elaborar este artigo percorri um conjunto de autores e reflexões onde, predominantemente, a conflitualidade não estava presente.

Encontrar diálogo com poucos autores e vislumbrar a possibilidade de enriquecer o debate através de uma leitura autêntica do território considerando a conflitualidade alimentou ainda mais o meu anseio. Outro fato determinante foi a predominância de leituras lacunares realizadas por alguns geógrafos em relação ao território e à conflitualidade e a falta de criticidade para reconhecer a correlação de forças no e entre os territórios. Portanto, este artigo é resultado de uma necessidade de explicar o território não somente pela relação de poder, mas também pela conflitualidade, visto que toda relação de poder pressupõe uma conflitualidade.

O artigo está organizado em três partes complementares. Na primeira parte realizamos um ensaio acerca de uma leitura geográfica da conflitualidade focando o conceito de território. Na segunda parte remontamos as mudanças da conjuntura política no país desde 1988 até o governo Lula relacionando-as com os avanços e refluxos das ocupações de terras. E por fim, na terceira parte trazemos um conjunto de elementos, processos e mudanças que nos possibilite pensar as transformações e novas dinâmicas na luta pela terra e ocupações de terra focando o governo Lula. 


\section{ENSAIO SOBRE UMA LEITURA GEOGRÁFICA DA CONFLITUALIDADE}

A questão agrária brasileira é consequiência do complexo processo de colonização, ocupação territorial e do avanço do modo capitalista de produção no campo, que historicamente tem se apropriado dos meios produção engendrando problemas estruturais na sociedade revelando sua face perversa como, por exemplo: a expropriação; o desemprego, a concentração fundiária e de renda; a exclusão; a exploração, a destruição e assalariamento do campesinato, etc. (Fernandes, 2008; Martins, 1981). Contudo, simultaneamente e contraditoriamente à criação e avanço destes processos sócio-metabólicos, são geradas formas de luta e resistência que se expressam em conflitos cotidianamente retratados nas pesquisas científicas e meios de comunicação.

No bojo deste complexo de contraditoriedades e processualidades destrutivas e conflituosas produzidas pela lógica capitalista no campo, a ocupação de terra é um elemento imprescindível para compreendermos tanto o caráter conflituoso da questão agrária brasileira. A princípio, destacamos dois motivos basilares que ressaltam a sua importância: 1) historicamente alguns movimentos socioterritoriais ${ }^{1}$ camponeses a vêem como parte fundamental e até mesmo a essência em sua constituição (Stedile, Fernandes, 1999) e organização expressando-se em múltiplas dimensões (cultural/simbólica, política, social, etc.), 2) sendo uma ação contestativa e combativa, impulsiona à transformação da realidade de maneira localizada ou, quando mais efetiva, impacta causando mudanças que atingem problemas estruturais, como: desapropriações, criação de um assentamento, políticas de reforma agrária em geral, políticas de produção voltada para os pequenos produtores, etc. ${ }^{2}$. Deste modo, as ocupações são realizadas por diversos movimentos sociais camponeses em todo o Brasil e em alguns lugares são mais intensas devido às especificidades da tensão da luta pela terra, como mostramos nos mapas 1 e 2.

\footnotetext{
${ }^{1}$ Sobre o conceito de movimentos socioterritoriais ver Fernandes (2005), Pedon (2009) e Sobreiro Filho (2011)

${ }^{2}$ Contudo, estas ações comumente ocorrem a custo da criminalização de muitas lideranças e em âmbito geral arremete à judiciarização da luta pela terra.
} 
Mapa 1 - Brasil - Geografia das Ocupações de Terra - 1988-2010 Número de Ocupações

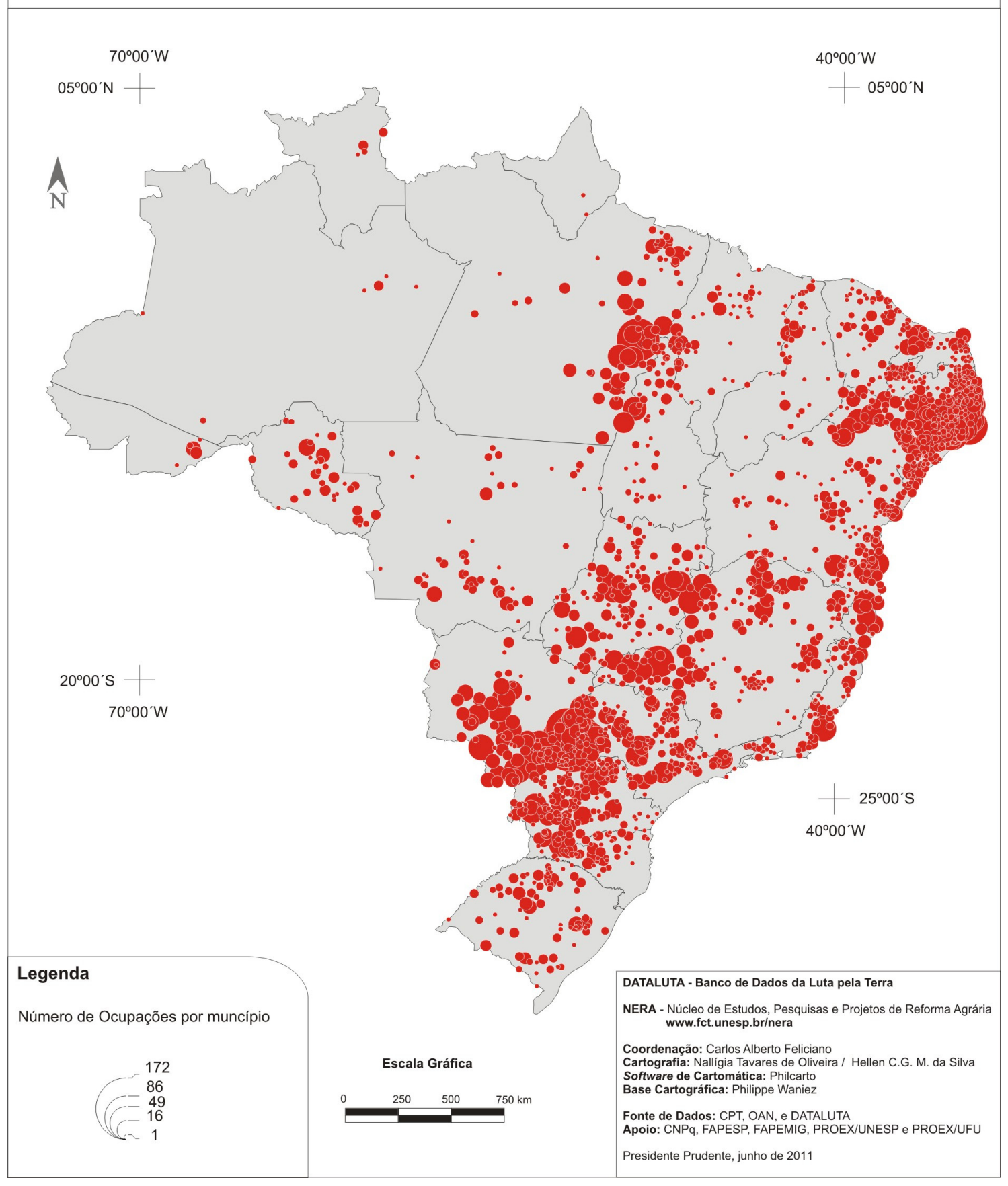




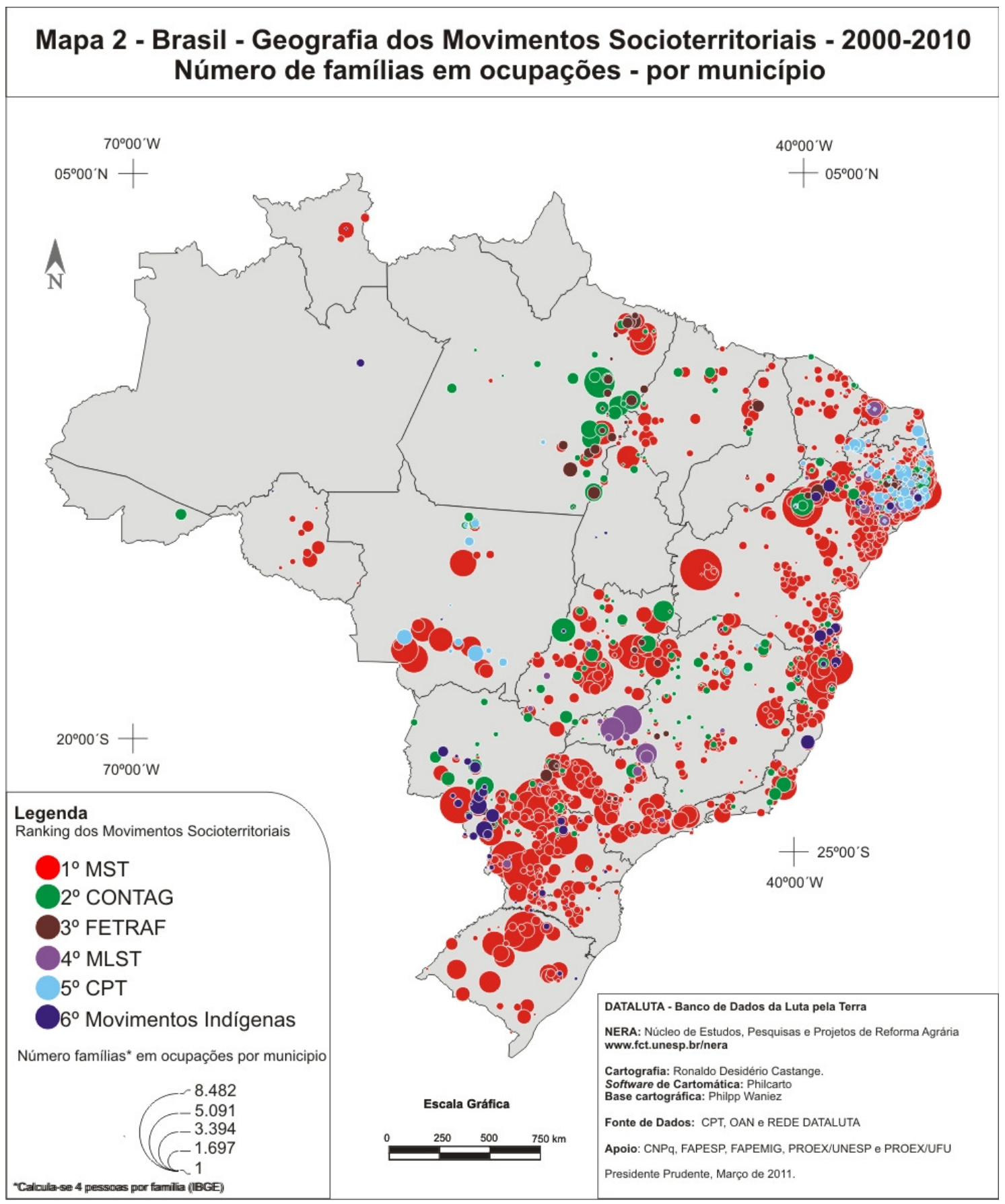

Portanto, o nexo de se realizar uma análise geográfica das ocupações de terra deve-se tanto à natureza da própria ação, mas também como condição sine qua non para compreendermos a sua complexidade, visto que temos como ponto de partida a necessidade do homem em relação ao espaço para se reproduzir socialmente, de modo que esse é um dos problemas centrais da questão agrária, ou seja, a necessidade da conquista e resistência em um espaço/território.

Atualmente, essa realidade de disputa de modelos de produção está intrinsecamente atrelada às disputas territoriais e ambas são permeadas por relações intensamente conflituosas. A conflitualidade ganha importância neste contexto por ser elemento manifesto no processo e desvendar relações de poder que compõem os territórios e as contradições do nosso modelo de sociedade. O território é central por compreender 
elementos característicos dos distintos modos de produção que se conflitam e/ou se subalternizam ou não, por ser a materialização da conflitualidade e recriá-la constantemente, por dar substrato para o desenvolvimento das contradições e demais conflitualidades, e em síntese por viabilizar e representar a conflitualidade desde seu processo de criação, manutenção e fim/recriação.

Portanto, a conflitualidade é elemento imprescindível para compreendermos a gênese, estrutura, dinâmica e processualidades ${ }^{3}$ do e que ocorrem no território. A conflitualidade é produto da questão agrária, é orgânica e inerente ao processo, é consequiência da contraditoriedade das relações capitalistas e, portanto, faz parte da natureza do modo capitalista de produção. Fernandes (2008) contribui significativamente destacando-a como produto da questão agrária e suas implicações no controle político sob o enfoque do desenvolvimento territorial:

Por essa razão, a questão agrária gera continuamente conflitualidade. Porque é movimento de destruição e recriação de relações sociais: de territorialização, desterritorialização, e reterritorialização do capital e do campesinato; de monopólio do território camponês pelo capital (Oliveira, 1991, p. 24-5). A conflitualidade é o processo de enfrentamento perene que explicita o paradoxo das contradições e as desigualdades do sistema capitalista evidenciando a necessidade do debate permanente, nos planos teóricos e práticos, a respeito do controle político e de modelos de desenvolvimento. (Fernandes, 2008. p. 5).

Dois pontos chamam a atenção. No primeiro destaca-se que a conflitualidade é um processo gerado pela questão agrária. Em seguida evidencia-se a conflitualidade na questão agrária através da destruição e recriação das relações sociais expressas nos processos de territorialização, desterritorialização e re-territorialização e, por fim, retoma a idéia inicial da conflitualidade como parte da questão agrária destacando o controle político acerca dos modelos de desenvolvimento territorial. Ademais, este enfoque territorial embasado em uma perspectiva geográfica nos permite compreender a conflitualidade tendo como principal referência, além das relações sociais, a materialidade $^{4}$ e, sobretudo, sua base territorial.

Ao discutirmos a questão agrária brasileira é imprescindível reconhecer que a conflitualidade faz parte da gênese do processo de formação tanto do campesinato quanto do capitalismo no campo e o respectivo antagonismo como destaca Fernandes:

A conflitualidade é inerente ao processo de formação do capitalismo e do campesinato. Ela acontece por causa da contradição criada pela destruição, criação e recriação simultâneas dessas relações sociais. A conflitualidade é inerente ao processo de formação do capitalismo e do campesinato por causa do paradoxo gerado pela contradição estrutural. (Fernandes, 2008. p. 6)

\footnotetext{
${ }^{3}$ Alguns autores tem uma visão romântica da discussão territorial, sendo omissos com o conflito. Essas análises mais brandas contribuem para inúmeras reflexões e pesquisas mancas, deixando de lado uma parcela da realidade tão próxima e presente no dia-a-dia.

${ }^{4}$ Aqui entendemos a materialização das relações sociais no espaço.
} 
Deste modo, também não fica difícil vislumbrar que, a conflitualidade está presente no início $^{5}$ (conquista), meio (manutenção/resistência) e fim/início (destruição e criação ou recriação) da existência do território ${ }^{6}$. Pois a conflitualidade é um processo de luta pela resistência, conquista e destruição que simultaneamente e conseqüentemente cria e/ou recria outro território. Portanto, a conflitualidade não leva ao fim do território, mas ao fim de um tipo de território específico (por exemplo: camponês, indígena, quilombola, etc.) porque destrói a partir do processo de criação ou recriação de outro território. Vale ressaltar, para evitar confusões, que a conflitualidade não levará ao fim do território, pois este só se findará através do fim da vida.

Assim, no bojo de uma questão agrária atual balizada pela intensa disputa territorial, a conflitualidade surge como o produto que dá unidade às diversas problemáticas estruturais que compõem a questão agrária e as revelam. Contudo, ainda hoje é comum que seja interpretada de maneira preconceituosa, maniqueísta e aparta do processo de desenvolvimento, como sê a conflitualidade expressa nas ocupações de terras não se constituíssem também como via para o desenvolvimento. Está concepção resulta na maioria dos casos em compreensões pejorativas do conflito ${ }^{7}$ e em reais entraves ao desenvolvimento pela vias ditas democráticas.

O Presidente FHC - Fernando Henrique Cardoso foi um dos governantes que agiu em defesa da manutenção da lógica vigente. A utilização do Estado para garantir a proteção dos interesses dos latifundiários é nítida na medida provisória 2109-52 aprovada em 2001, que foi um dos principais exemplos de uma via de contensão do processo de espacialização da luta pela terra que focava as ocupações de terra, assim por consequiência evitando possíveis "ameaças" à integridade da propriedade privada capitalista $^{8}$. A medida provisória $2109-52$ de 24 de maio de 2001 foi uma estratégia de judiciarização da luta pela terra que criminaliza as famílias participantes de ocupações de terra e privilegiava a propriedade privada latifundiária, visto que não poderia ser desapropriado durante o período de dois anos.

Fernandes (2008) destaca a visão pejorada e obstrucionista do conflito e o evidencia como parte das próprias contradições do capitalismo:

Há, inclusive, uma compreensão predominante de que o conflito prejudica o desenvolvimento. Confrontando essa visão afirmamos que o conflito agrário e desenvolvimento são processos inerentes da contradição estrutural do capitalismo e paradoxalmente acontecem simultaneamente. (Fernandes, 2008. p. 2).

É evidente que para alguns o conflito é sinônimo de atraso e deve ser evitado por ser um obstáculo ao desenvolvimento ${ }^{9}$. Em muitos casos, a conflitualidade não é compreendida

\footnotetext{
${ }^{6}$ Vale ressaltar que a perda do território só ocorre devido à outra conquista, situação tal que caracteriza um processo constante.

${ }^{8}$ A questionabilidade de algumas propriedades tidas como particulares e a função social das propriedades são fatores fundamentais na luta pela terra em várias regiões como o Pontal do Paranapanema.

9 Aqui vale lembrar também... que o conflito ele serve justamente para questionar o projeto de desenvolvimento. Também uma visão que vai contra a compreensão de que entende o conflito como
} 
como parte dos processos e da natureza do capitalismo, mas como aquilo que impede o desenvolvimento, que se impõe como um entrave, etc., e em alguns casos até omitido intencionalmente ${ }^{10}$. É sabido que este modo de entender e lidar com a conflitualidade é fruto da formação intelectual, opção ideológica, conjuntura histórica, vinculação paradigmática e, balandrau, de uma intencionalidade específica de cada sujeito político (Searle, 2002). Contudo, algumas opções e embasamentos podem também nos levar a erros escatológicos, sendo então negligentes com a realidade e realizando uma ciência e políticas cada vez mais parciais.

Outra leitura possível é da conflitualidade como um elemento fundamental para se alcançar novos e outros modelos e modelos de desenvolvimento. Este outro modo de ver e analisar a conflitualidade ampara-se na compreensão do movimento dialético da realidade e, portanto, o constante exercício de uma conflitualidade pela via dialética nos permitiria obter resultados mais qualificados. Assim, de maneira objetiva, essa conflitualidade pode ser realizada tanto com iguais, por exemplo, em discussões entre lideranças de um mesmo movimento camponês, quanto com diferentes, como em ocupações de terra, ou seja, pode ser tanto entre classes quanto intra-classe, pois, amparada na filosofia da práxis, refere-se a outro modo de interpretar e interagir com o espaço geográfico. Isso não quer dizer que não há consenso, mas que através da conflitualidade pode-se alcançar um salto qualitativo superior e que o consenso é alcançado, definido e apurado por meio da conflitualidade ${ }^{11}$.

Neste sentido, sob o olhar geográfico, a conflitualidade é o combustível que move as engrenagens dos processos de territorialização, desterritorialização e re-territorialização. Ela é responsável, em partes, pela constante reorganização do espaço e a geografia, pela sua base epistemológica, surge com um significativo potencial explicativo e analítico acerca da questão e seus processos. A importância de uma análise pela via da conflitualidade é evidente ao nos atermos às lutas dos movimentos socioterritoriais camponeses no Brasil, sobretudo, tendo como foco às ocupações de terra visto que atingem diretamente $\mathrm{o}$ território material, imaterial em respectivas multidimensionalidade. Como exemplo do resultado das lutas dos movimentos socioterritoriais camponeses temos a realização de políticas de assentamentos rurais (Fernandes, 2000), conforme mapa 2.

obstaculosa e a gestão como o super-herói que vai resolver o conflito, mas o conflito é que vai melhorar a gestão.

${ }^{10}$ Em Fernandes (2008) e Felício (2006) o PCA - Paradigma do Capitalismo Agrário não reconhece a existência de uma Questão Agrária.

${ }^{11}$ Em alguns casos o consenso pode ser pelo conflito ou pela sua retomada. 


\section{Mapa 3 - Brasil - Geografia dos Assentamentos Rurais - 1979-2010 Número de Assentamentos}

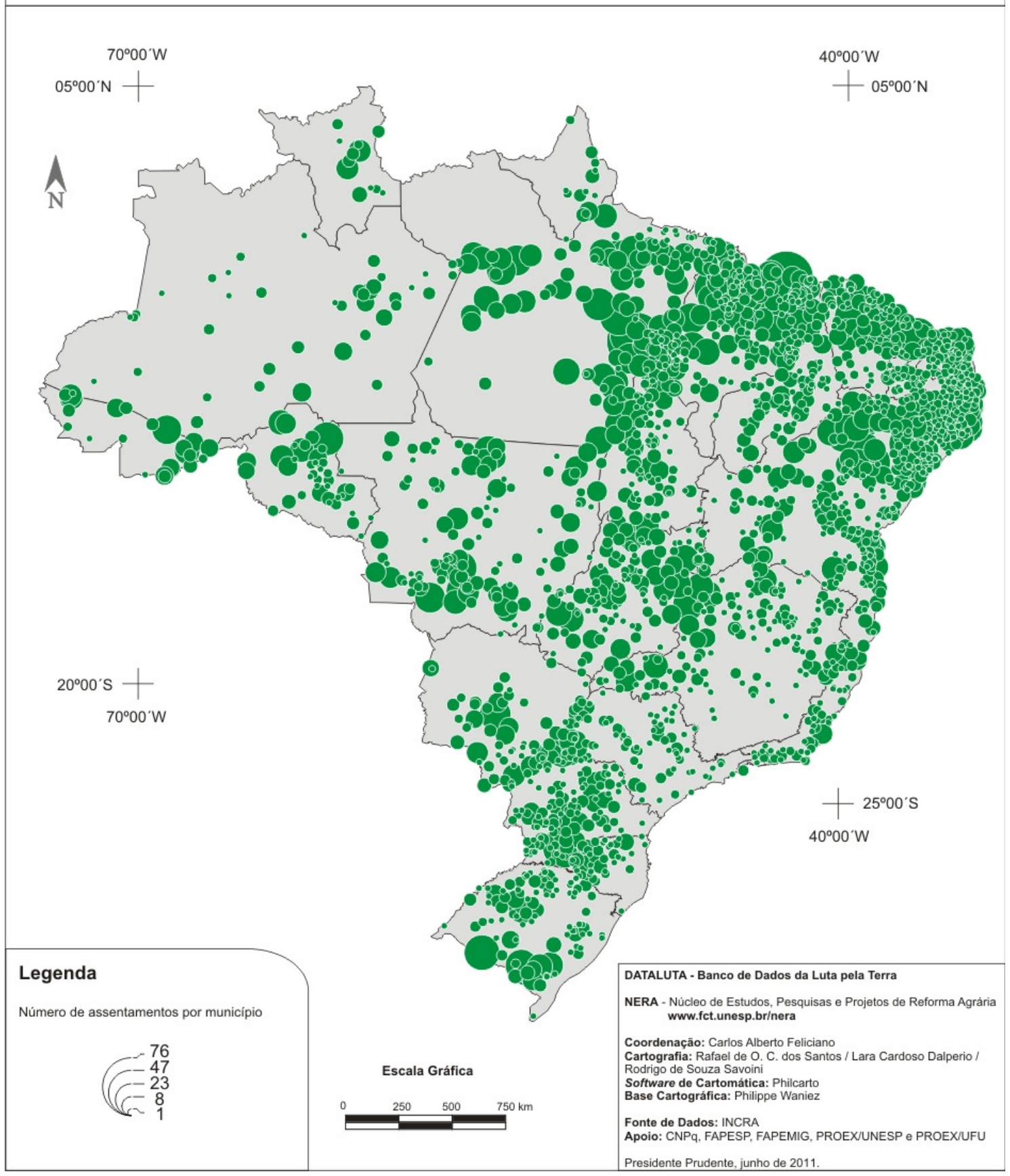

Deste modo, sendo a conflitualidade uma relação social e compreendendo que o território não é somente material (Fernandes, 2008; Souza, 2009; Saquet, 2009 e 2010), a conflitualidade transita e se expressa tanto na materialidade quanto na imaterialidade sendo início/criação, fim/destruição e recriação do território material/imaterial em um processo dialético e constante ${ }^{12}$. A sua inrregistribilidade é pictórica, pois na produção e disputa territorial a materialidade e imaterialidade são indissociáveis e se produzem e reproduzem recíproca e constantemente. Em síntese, a conflitualidade não é somente material, mas também imaterial, de modo que se realiza no plano paradigmático,

\footnotetext{
${ }^{12}$ Podemos interpretar a conflitualidade sob o enfoque de diferentes métodos. Para a dialética a constância é parte intrínseca e fundamental da evolução do processo.
} 
ideológico, intencional, sentimental, na construção do conhecimento científico e comum, etc., e se expressa no espaço em forma de territórios e territorialidades.

Esse processo pode ser visto no antagonismo da luta entre os movimentos socioterritoriais camponeses e o Agronegócio que disputam e se conflitam em espaços na mídia, no congresso nacional, nas universidades, nas ocupações de terra, projetos de desenvolvimento territorial, etc. De acordo com Fernandes (2008) "Os conflitos por terra são também conflitos pela imposição de modelos de desenvolvimento "territorial" rural e nestes se desdobram". ( $p$. 2) essa compreensão parte do reconhecimento legítimo de que a conflitualidade pode ser utilizada para se alcançar e impor e efetivar modelos de desenvolvimento territorial ${ }^{13}$.

Deste modo, seria um deslize pensarmos a questão agrária, o desenvolvimento territorial, as ocupações de terra e a própria luta pela terra aparta da conflitualidade. Enveredar por este caminho nos levaria a uma leitura lacunar e desconexa da realidade por negligenciarmos um conjunto de sujeitos, elementos e fatos que interferem diretamente na produção do espaço/território e imprimem suas ações na história.

O conflito no campo faz parte da trajetória de luta dos movimentos camponeses como podemos ver em Fernandes (1994, 2000) Feliciano (2006) e Martins (1981). Essa leitura não é exclusiva da academia, pois cotidianamente os meios de informações também divulgam notícias de conflitos. Como já dissemos, reconhecê-los é uma questão de método, vinculação paradigmática, filiação político-ideológica e intencionalidade de cada sujeito político.

Assim, sob um olhar geográfico crítico, a conflitualidade intrinsecamente está atrelada às relações de ao poder/domínio, subordinação do espaço e à disputa territorial, tornando-se clara a eminência do complexo categorial "território" nesta discussão, visto a emersão da conflitualidade em sua constituição genética a partir do estabelecimento de relações de poder e correlações de força no espaço e, tão logo, nas implicações em demais relações socioespaciais.

Atualmente, a categoria território tem sido amplamente estudada pelas ciências humanas ${ }^{14}$ e utilizada na elaboração de políticas públicas. A geografia tem trazido grandes contribuições acerca da sua compreensão. Para se discutir território e a conflitualidade é fundamental relevar a importância de se pensar o poder ${ }^{15}$. Um dos referenciais mais importantes para esta reflexão é Claude Raffestin (1993). Embora sua obra não esteja centrada em uma análise categorial ou visar a construção conceitual Raffestin em "Por uma Geografia do Poder" trás contribuições significativas para que possamos entender o território através das relações de poder. Portando, sua abordagem não se reduz ao conceito de território, mas nos permite compreender como o poder está implícito em todas as relações sociais e em suas expressões no espaço ${ }^{16}$ :

\footnotetext{
${ }^{13}$ Vale ressaltar que no caso dos movimentos socioterritoriais camponeses muitos conflitos referem-se à recusa da imposição hierárquica de modelos de desenvolvimento territorial rural, pois os movimentos visam cada vez mais ganhar espaço de acordo com as suas necessidades e especificidades.

${ }^{14}$ Ao importarmos alguns conceitos de outras disciplinas podemos trazer consigo limitações crônicas (ver Sobreiro Filho, 2011)

${ }^{15}$ Conflito e poder são indissociáveis. O poder da condição para a existência do conflito e o conflito só existe é criado devido à existência do poder.

${ }^{16}$ É importante ressaltar que o poder está explícito em todos os conceitos-chaves da ciência geográfica.
} 
O poder é parte intrínseca de toda relação. Multidimensionalidade e imanência do poder em oposição à unidimensionalidade e à transcendência: "O poder está em todo lugar; não que englobe tudo, mas vem de todos os lugares". Portanto, seria inútil procurar o poder "na existência original de um ponto central, num centro único de soberania de onde irradiam formas derivadas e descendentes, pois é o alicerce móvel das relações de força que, por sua desigualdade, induzem sem cessar a estados de poder, porém sempre locais e instáveis. (Raffestin, 1993, p. 52)

Ainda que Raffestin dê a devida importância ao "poder" em sua discussão acerca das relações sociais e da sua expressão no espaço e território, o conflito ainda permanece em segundo plano, afinal o autor não se dispõe a tal objetivo. Contudo, sua contribuição nos dá subsídios importantes para reconhecer a conflitualidade, pensá-la e avançar, pois o mesmo reconhece o confronto e que o poder se revela também por meio de processos divergentes:

O poder se manifesta por ocasião da relação. É um processo de troca ou de comunicação quando, na relação que se estabelece os dois pólos fazem face um ao outro ou se confrontam. As forças de que dispõem os dois parceiros (caso mais simples) criam um campo: o campo do poder. (Raffestin, 1993. p. 53. Grifo nosso)

Essa abordagem geográfica sobre o território privilegiando as relações de poder contribui significativamente por evidenciar a correlação de forças existente ${ }^{17}$. Neste sentido outras reflexões são adequadas e complementares para pensarmos e identificarmos a conflitualidade no(s) território(s) através do olhar geográfico.

A leitura da multiterritorialidade de Haesbaert (2004) multiescalaridade de Fernandes (2008), multidimensionalidade de Haesbaert (2004), Fernandes (2008), Saquet (2009; 2010) e Souza (2009), e a tipologia de territórios de Fernandes (2008), nos permitem identificar as contradições e conflitualidade existentes no espaço e territórios, entre os territórios e intra-território.

Portanto, são leituras que possibilitam reconhecer a conflitualidade horizontal, vertical e transversalmente, que permite identificá-la pontualmente, de acordo com suas especificidades, e também reconhecê-la como parte de um todo, em uma visão da realidade em sua totalidade. São leituras que nos permite identificar a heterogeneidade das relações, espaço/territórios e, conseqüentemente, da conflitualidade. São instrumentais de leitura e análise que nos auxilia ir além de uma visão homogênea do território e compreender suas relações intra e entre territórios e ampliar nossos referenciais e perspectivas de análise.

\footnotetext{
${ }^{17}$ São poucos geógrafos que se dedicaram a entender a conflitualidade, sobretudo, compreendê-la no espaço ou território.
} 


\section{A CONJUNTURA POLÍTICA NO BRASIL E AS OCUPAÇÕES DE TERRA}

No ano de 1988 foi decretada e promulgada pela Assembléia Nacional Constituinte a Constituição Federal de 1988, dando forma ao regime político vigente. As principais mudanças referem-se ao direito ao voto direto e secreto, a instituição de uma ordem econômica que tem por base a função social da propriedade e a limitação da liberdade de iniciativa pelo Estado. Na luta pela terra a importância destas transformações foi na instauração da democracia e a facilitação das ocupações de terras e desapropriações ${ }^{18}$ que começam a crescer. A idéia de uma democracia surge como uma estratégia política para estimular o juízo da igualdade e liberdade. Contudo, a bancada ruralista continuou assegurando seus interesses e direcionando políticas públicas para os grandes produtores rurais. Stedile e Fernandes (1999) evidenciam esse processo como uma significativa perda:

\footnotetext{
A UDR teve muita influência nos governos estaduais e, principalmente, na Constituinte de 1988. Praticamente a única derrota que ocorreu na Constituinte foi na questão agrária, pois em todos os outros itens houve avanços (p. 67).
}

Com as perdas no campo político, os conflitos e a repressão às idéias combativas continuaram a se expressar no campo. Um dos mais notórios casos neste período foi o assassinato, a mando de latifundiários, do líder Chico Mendes ${ }^{19}$. A morte do líder sindical defensor dos seringueiros e do meio ambiente marcou os ativistas que lutavam contra os exploradores, atingindo repercussão mundial devido a sua luta pela justiça e violência contra um dos principais representantes da classe trabalhadora e populações tradicionais.

As eleições de 1989 foram determinantes para o aumento das ocupações de terra, que em relação ao ano anterior aprensentou crescimento de $21,12 \%$ e famílias em ocupações, quase dobrando com um aumento de 93,97\%, evidenciando que os movimentos camponeses estavam fortalecendo suas lutas, querendo participação ativa nos governos e que as ocupações de terra deveriam ser encaradas como um sinal de que a população demandava a realização da reforma agrária e transformações políticas no país que sinalizassem a realização da reforma agrária e melhores condições de vida (ver gráficos 1 e 2).

\footnotetext{
${ }^{18}$ No Artigo 184da constituição Federal - Compete à União desapropriar por interesse social, para fins de reforma agrária, o imóvel rural que não esteja cumprindo sua função social, mediante prévia e justa indenização em títulos da dívida agrária, com cláusula de preservação do valor real, resgatáveis no prazo de até vinte anos, a partir do segundo ano de sua emissão, e cuja utilização será definida em lei.

${ }^{19}$ Assassinado por fazendeiros ligados à UDR (Stedile e Fernandes, 1999).
} 


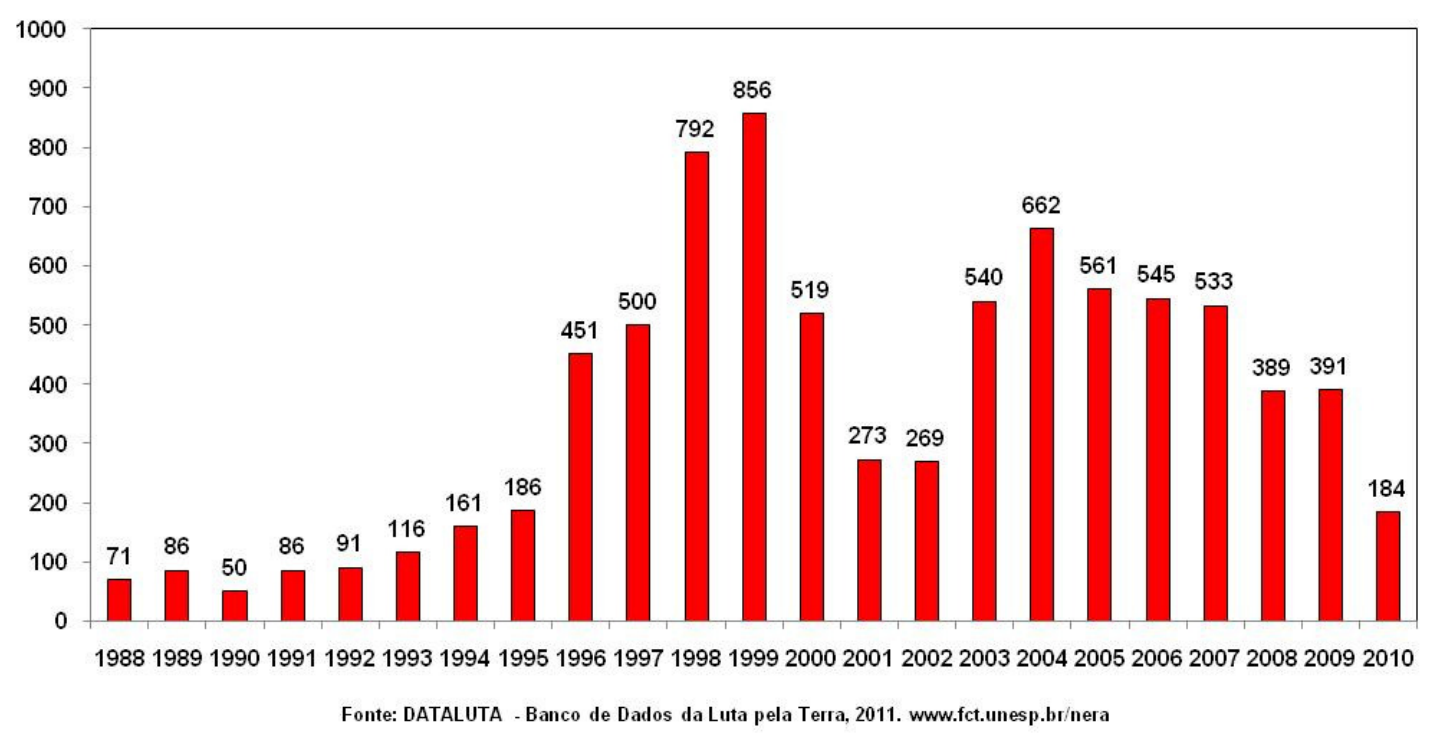

Ainda em 1989, Fernando Collor de Mello do PTB - Partido Trabalhista Brasileiro ${ }^{20}$ foi eleito Presidente da República. O mandato do governo de Collor iniciado em 1990 foi marcado pela implementação do Plano Collor que viabilizou a abertura do mercado nacional para as importações e o processo de privatização das empresas estatais. A abertura da economia brasileira, o apoio aos latifundiários e a implantação do neoliberalismo foram os principais fatores que marcaram e asseverarm a luta pela terra durante seu perído de governo.

Coletti (2006) ressalta o expressivo crescimento da luta pela terra e expressão do MST no cenário político:

É inegável o expressivo crescimento da luta pela terra no Brasil na década de 1990, no contexto da implementação das políticas neoliberais em nosso país. Os números de ocupações de terra, de acampamentos, de manifestações públicas em favor da reforma agrária etc. confirmam essa informação. Relacionado diretamente a esse fato, está o crescimento do Movimento dos Trabalhadores Rurais Sem Terra (MST), que se transformou na maior expressão política da luta pela terra e pela reforma agrária e no mais importante movimento social de oposição ao projeto neoliberal no Brasil. (Coletti, 2006 131)

As políticas públicas para a agricultura foram restringidas ao máximo e as atribuições a favor da Reforma Agrária se esvairam, principalmente com o fim do Ministério da Reforma Agrária e do Desenvolvimento Agrário. O comprometimento com os interesses da classe ruralista implicava na não realização da reforma agrária, relutando na realização das politícas de reforma agrária e acarretando forte repreessão aos movimentos camponeses. De acordo com Stedile e Fernandes (1999) a repressão foi intensa:

\footnotetext{
${ }^{20}$ Fernando Collor de Mello foi o primeiro presidente a ser eleito com o voto direto após o regime militar.
} 
O governo Collor, além de não faze a reforma agrária, resolveu reprimir o MST. Acionou a Política Federal, o que é uma agravante, pois não é uma tropa de choque, é repressão política pura. $\mathrm{O}$ agente da Polícia Federal é um sujeito mais preparado, mais sedimentado. Não batiam mais nas nossas canelas, batiam na cabeça. Essa repressão nos afetou muito, muita gente foi presa. Começaram a fazer escuta eletrônica. Tivemos, no mínimo, quatro secretarias estaduais invadidas pela Polícia Federal. (Stedile e Fernandes, 1999, p. 69)

A consequência das ações e posicionamento opressor do governo impactou com uma queda das ocupações de terra em 41,86\% (ver gráfico 1) e de 64,05\% das famílias em ocupações de terra (ver gráico 2) dos anos de 1989 para 1990.

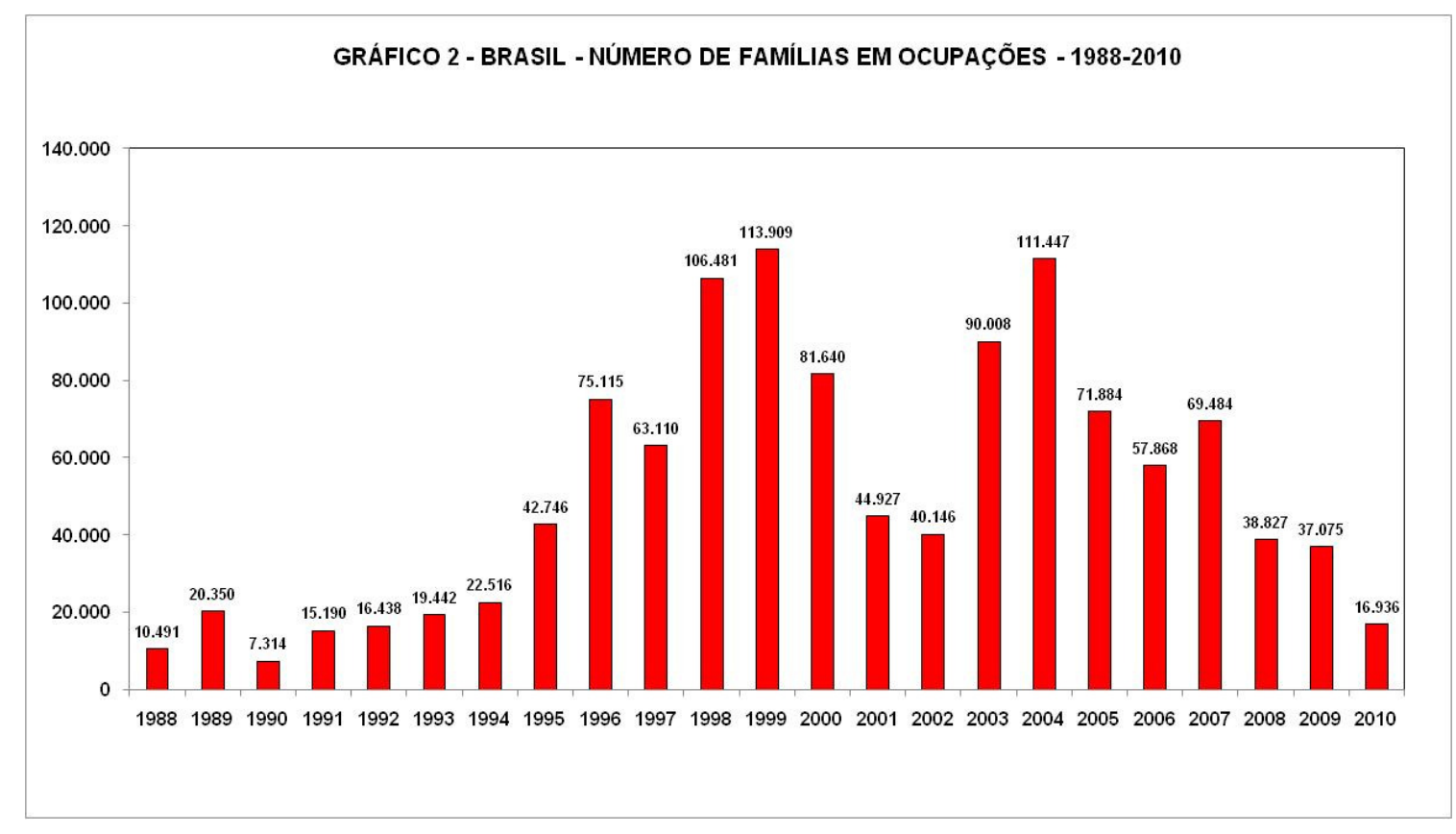

Perante a conjuntura de opressões e resistência, movimentos como o MST Movimentos dos Trabalhadores Rurais Sem Terra se organizaram para discutir as perspectivas da Luta pela terra no país e suplantar estratégias eficientes que lhes garantissem o acesso à terra e realização da reforma agrária. Foi realizado em Brasília, entre os dias 8 e 10 de maio, o $2^{\circ}$ Encontro Nacional do $\mathrm{MST}^{21}$. Durante o Congresso foi reafirmado o lema de luta "Ocupar, Resistir e Produzir". O encontro visava fortalecer os vínculos da luta pela terra.

Apesar da repressão contra os movimentos camponeses e o apoio à classe latifundiária durante o governo Collor, as ações do movimentos voltaram a crescer em 1991, aumentando as ocupações em 72\% e o número de famílias em ocupações em 107,68. Este aumento deve-se aos encontros e à organização dos movimentos para lutar pela

\footnotetext{
${ }^{21} \mathrm{O}$ evento contou com a participação de 5 mil delegados de todo o Brasil e 10 delegações estrangeiras, facilitando o intercâmbio de experiências de luta e atuações com os governos.
} 
resistência, reforma agrária e compreensão de que a realização das ocupações ${ }^{22}$ é fundamental para se alcançar a reforma agrária.

Em 1992 o cenário político é novamente alterado. Fundamentado em acusações de corrupção ocorre o Impeachment do presidente Fernando Collor de Mello. Com o Impeachment de Collor no dia 29 de Setembro de 1992 o vice-presidente Itamar Franco assumiu a presidência no dia 2 de outubro ${ }^{23}$. Durante o primeiro ano de governo de Itamar Franco, 1993, os números de conflitos por ocupações de terras continuaram a aumentar. $\mathrm{O}$ aumento está diretamente relacionado à maior possibilidade de diálogo entre Itamar e os movimentos ${ }^{24}$. Em Stedile e Fernandes (1999) fica evidente como a alteração do governo impactou em uma melhoria para o MST:

É, existia o sentimento de que era preciso resistir. Por outro lado, a direita se viu vitoriosa, por que alterou a correlação de forças. E passou a pressionar nos estados, por meio dos governadores, das PMs, da articulação dos fazendeiros. Etc.

Foi uma loucura. Foram três anos comendo o pão que o diabo amassou. A entrada do governo Itamar Franco foi um alívio muito grande. Do ponto de vista das conquistas, reabriu um período semelhante ao da Nova República, embora mais atrasado (p. 70).

Em relação aos três anos anteriores os números ocupações e famílias em ocupações cresceram. No entanto, assim como a intensidade da luta pela terra aumentou também cresceram os casos de repreensão e violência ${ }^{25}$ contras integrantes dos movimentos socioterritoriais camponeses seguindo a tendência repreensiva. Não obstante, quanto maior a repreensão e a violência contra os movimentos maiores foram os números de ocupações e famílias em ocupações de terra.

Outro fator que determinou o aumento das ocupações de terra e conflitos no campo durante o período foi a conjuntura econômica do país, que enfrentava dificuldades com a crise inflacionária ${ }^{26}$. Mesmo com a melhoria da economia brasileira os conflitos pela terra continuaram a aumentar e não foram alteradas as tensas relações dos movimentos com o governo. Nesse período os movimentos realizavam manifestações levantando as bandeiras contra o processo de privatização das grandes empresas estatais, como a CSN - Companhia Siderúrgica Nacional, que foi privatizada no Programa Nacional de Desestatização levado a cabo pelo governo federal, durante os mandatos de Fernando Collor e Itamar Franco.

\footnotetext{
${ }^{22}$ Neste mesmo período a luta pela terra no Brasil ganhou maior reconhecimento internacional quando a CPT e o MST receberam no dia 09/12 em Estocolmo na Suécia o premio Nobel Alternativo, entregue às organizações que lutam pelo direito à vida no $3^{\circ}$ mundo.

${ }^{23}$ Contudo, somente no dia 29 de dezembro, quando Collor renunciou o cargo que Itamar Franco foi aclamado formalmente o presidente da republica.

${ }^{24}$ Sentar, negociar e nos das status de interlocutor político, somente com o governo Itamar. (Stedile e Fernandes, 1999, P. 70)

${ }^{25}$ No dia 08 de Março de 1993, o militante do MST conhecido como Teixeirinha, líder do acampamento Campo Bonito no Estado do Paraná, foi assassinado após ter sido torturado diante da família e amigos pelo GDE - Grupo de Operações Especiais da Polícia Militar do Paraná.

${ }_{26}$ Justamente com o sentido de combater a crise inflacionária que o presidente Itamar Franco lançou o Plano Real idealizado pelo economista Edmar Bacha e posto em prática durante a gestão do ministro da fazenda FHC - Fernando Henrique Cardoso. O Plano Real teve sucesso contra a inflação e aumentou a popularidade do ministro da fazenda que posteriormente viria a ser o presidente da república, sucedendo $o$ presidente Itamar Franco.
} 
A luta contra a privatização caminhava no sentido de defender os interesses da classe trabalhadora e combater o fortalecimento do modelo neoliberal, da exploração brutal e apropriação das riquezas nacionais por parte das multinacionais em detrimento do afastamento do Estado $^{27}$. Em 1994, com forte apoio da população, principalmente da classe mais abastada, devido ao sucesso do Plano Real, Fernando Henrique Cardoso candidatou-se para as eleições e foi eleito. O governo FHC marcou fortemente a luta pela terra devido ao aumento da resistência em negociar com os movimentos sociais e a intensificação da criminalização e repreensão.

No ano de 1995, em Brasília, entre os dias 24 e 27 de julho foi realizado o $3^{\circ}$ Congresso Nacional do MST com a participação de cinco mil delegados de todo o país ${ }^{28}$. Durante o congresso foi lançado o lema "Reforma Agrária uma luta de Todos" que evidenciava que toda a sociedade seria beneficiada com a realização da Reforma Agrária e que também objetivava trazer toda a sociedade para fortalecer e entender a luta ${ }^{29}$. Visto que os movimentos compreendiam a necessidade da participação e da conscientização da sociedade sobre a luta pela terra e de seus benefícios para com os mesmos, as ocupações ganharam maior sentido e se tornaram cada vez mais o símbolo da confrontação com o território do capital e da lógica dominante ${ }^{30}$. Desta maneira, devido ao crescimento dos movimentos socioterritoriais camponeses o governo FHC passou a intensificar a repreensão e a resistência para negociar com os movimentos, visando o enfraquecimento através do isolamento político.

Um dos maiores escândalos e exemplo da violência e repressão do governo $\mathrm{FHC}$ em suas violentas increpações às ocupações de terra foi o massacre de Corumbiara no dia 9 de agosto no município de Corumbiara no Estado de Rondônia. O conflito ocorrido entre policiais, jagunços e camponeses sem terra que realizavam uma ocupação resultou em 12 mortes e várias vitimas de tortura. A ação brutal contra os ocupantes da fazenda Santa Elina foi mais uma demonstração das violentas repreensões contra os movimentos.

Diante da falta de negociação com o governo FHC os movimentos, entre os anos de 1994 e 1995, passaram a intensificar o número de ocupações em 15,52\% e famílias em ocupações em 142,47\% visando explicitar, acima de tudo, a necessidade da realização da reforma agrária no país e a sua indignação perante aos acontecimentos e a maneira conforme o governo vinha tratando do assunto. A intensificação das desigualdades causada pelo avanço do neoliberalismo durante o período de governo também implicou diretamente na luta pela terra. O capital estrangeiro se fortalecia cada vez mais,

\footnotetext{
${ }^{27}$ Os movimentos caminhavam no sentido do combate às políticas "entreguistas" de privatização das estatais brasileiras e essencialmente o modelo neoliberal de governo.

${ }^{28}$ É importante evidenciar que o MST teve papel fundamental no processo de organização, realização e evolução das ocupações no país. Outro fator importante sobre o MST é que vários outros movimentos se originaram através de uma dissidência do movimento, sendo assim, tendo como referencial organizativo o MST.

${ }^{29}$ No dia 24 de julho foi assassinado no caminho de volta do encontro com os posseiros que ocupavam a área da fazenda Catuva no município de Aripuanã (MT) o Pe. Ezequiel, que era um dos defensores da luta na região. $O$ fato ganhou reconhecimento internacional quando o Papa João Paulo II lamentou publicamente o fato e referiu-se a Ezequiel com um mártir da justiça e dos pobres que lutam pela terra.

${ }^{30}$ As ocupações conflitam com o capital em diferentes escalas (local, municipal, regional, estadual, nacional, continental e mundial) e com as diferentes dimensões (política, social, econômica, ambiental, etc.) por isso torna-se possível realizarmos uma leitura multiescalar e multidimensional das ocupações de terras.
} 
sobretudo, viabilizado pelos fortes incentivos dados pelo governo para a agroindústria de exportação.

No ano seguinte outro massacre ainda mais brutal marcou a luta pela terra. No dia 17 de Abril de 1996 a marcha por emprego e Reforma Agrária em Eldorado de Carajás no município de Eldorado do Carajás no Estado do Pará terminou com 19 sem-terras assassinados e mais de 100 pessoas feridas. A mando do governador Almir Gabriel do PSDB, do secretário de segurança pública Paulo Sette Câmara e de fazendeiros do Pará a policia militar ágil contra o bloqueio de uma pista realizada pelos manifestantes. $\mathrm{O}$ caso de Eldorado dos Carajás ganhou repercussão internacional devido à extrema violência com os manifestantes. Posteriormente o presidente FHC se posicionou lamentando o ocorrido e prometendo se dedicar para solucionar os problemas do campo. No mês de maio do mesmo ano o governo federal recriou o Ministério da Reforma Agrária que havia sido extinto desde o governo Collor.

No entanto, no mês de Junho outro conflito violento marcou a luta pela terra, no Estado do Maranhão um confronto entre sem-terras e latifundiários resultou em quatro mortos e cinco feridos. Tornou-se cada vez mais evidente a descrença do governo FHC sobre a agricultura camponesa e, sobretudo, na luta pela terra e suas causas através da desqualificação das ações dos movimentos através das criminalizações. As ações do governo, na maioria delas emergenciais, convergiam apenas com os momentos de mais tensos da luta e deixavam clara a sua preocupação com a manutenção da lógica vigente. Em relação ao ano de 1995 as ocupações aumentaram em 142\% e famílias em 75,72\% no ano de 1996.

Sobre este período, Stedile e Fernandes (1999) fazem uma leitura importante acerca da atuação do governo FHC em relação ao MST destacando duas premissas. A primeira refere-se a uma leitura de inexistência do problema agrário, assim a grande propriedade não se enquadraria como um empecilho. A segunda refere-se à subordinação da nação ao capitalismo internacional, abrindo o mercado, entregando a economia ao capital financeiro e arrolando a agricultura às margens ${ }^{31}$. Assim, de acordo com esses paramentos conjunturais, a repressão do governo FHC sobre o MST, principal movimento atuante e alvo de repressões no período, seguiu três variantes: a primeira era estimular o mercado de terras com a reforma agrária de mercado viabilizada pelo banco mundial; a segunda é a propaganda contra o MST objetivando desmoralizá-lo, enfraquecer o apoio da sociedade, criar a idéia de que era um inimigo da sociedade e entrave para o desenvolvimento; e o terceiro era o isolamento do MST.

No entanto, apesar das duras tentativas de repressão e isolamento durante este período, o governo não obteve o resultado que se esperava e o MST conseguiu se sobressair em alguns momentos e resistir na luta, conforme destaca Stedile e Fernandes (1999):

Para ele, o MST não existia. Derrotamos essa tática de uma maneira voluntária e também involuntária. A involuntária dói o massacre de Corumbiara (RO), em agosto de 1995, que revelou ao mundo a existência dos problemas agrários no Brasil. A voluntária dói o nosso III Congresso Nacional, em Brasília, com aquela passeata de 5 mil pessoas que nos recolocou na imprensa. "Olha, tem sem-terra aí, não

\footnotetext{
${ }^{31}$ Ver Stedile e Fernandes (1999, p. 139-40)
} 
vai dizer que esses caras não existem", dizia a cobertura da imprensa na época. (p. 143).

A tensão na luta pela terra continuou a aumentar. Em 1997 o MST realizou uma marcha de mil quilômetros rumo à Brasília, reunindo, na chegada dia 17 de abril, cerca de cem mil pessoas em uma marcha de protesto contra o governo FHC, sobretudo pelo isolamento promovido, e em memória ao massacre de Eldorado dos Carajás. De acordo com Stedile e Fernandes (1999) "Então fizemos uma marcha para estabelecer um canal de comunicação com a população, num momento em que o governo FHC procurava nos isolar da sociedade." (p. 152). A partir de 1997, o MST também organizou uma jornada de ocupações denominada de Abril Vermelho ${ }^{32}$ para lembrar o aniversário do massacre.

A relação entre o governo e os movimentos camponeses, sobretudo o MST, continuou a se estreitar no transcorrer dos anos e tornava-se cada vez mais evidente que a elite nacional não tinha interesse na efetivação da reforma agrária. Visto que os movimentos camponeses desaprovavam claramente a política do presidente FHC por seu apoio ao fortalecimento do neoliberalismo, pelo apoio à classe ruralista e pelo isolamento político que o presidente submetia os movimentos, as ocupações de terra ganham ainda mais significado e importância para evidenciar a realidade e as demandas da classe trabalhadora rural e o antagonismo entre classes.

Em 1998, ocorreu um crescente número de ocupações de terra $(58,4 \%)$, famílias em ocupações $(68,72 \%)$ e também o súbito aumento de ocupações de prédios e lugares públicos. A mudança e o aumento das ocupações referem-se ao ano eleitoral em que o atual presidente FHC tentava a re-eleição. A re-eleição de FHC surge como uma ameaça à classe trabalhadora rural, pois havia uma distancia significante entre os interesses dos mesmos com a política do PSDB e a nítida falta de diálogo.

Durante o Governo FHC outro processo importante que deve ser levado em conta ao analisarmos a luta pela terra é a formação de novos movimentos sociais. Diante da necessidade de desmoralizar o MST, que crescia cada vez mais no país e se tornava uma ameaça ao governo, o PSDB investiu estrategicamente na criação do MAST Movimento dos Agricultores Sem-Terra como um movimento criado para se opor ao MST e levantar a bandeira de uma "reforma agrária" pacífica. Sua formação deve à articulação da SDS - Social Democracia Sindical do PSDB - Partido da Social Democracia Brasileira com novos movimentos dissidentes do MST (Sobreiro Filho, 2011). Conforme Feliciano (1999), esta postura não apresentava nada de novo, apenas se aliava com a postura do governo em seu caráter liberal-democrático. Portanto, o MAST se prostrava como um movimento cujo projeto político esta alicerçado na corrente liberal do PSDB e subordinado ao governo FHC. Contudo, apesar deste novo elemento na luta pela terra, os conflitos continuaram a se intensificar no transcorrer dos anos e o MST persistiu se opondo ao governo. O presidente manteve sua postura de isolamento político e a elite nacional não tinha interesse na efetivação da reforma agrária. Neste contexto, o MST lança o lema "ocupar, resistir e produzir" durante o período de governo FHC para corroborar, dar novos rumos e estimular a luta.

\footnotetext{
${ }^{32}$ O Abril Vermelho tornou-se um símbolo da luta pela terra em que se realizam ocupações e manifestações com diversos objetivos. A jornada passou a ser realizada todo ano, e fazendo o mês de abril o mais conflituoso do ano.
} 
Em 1999, ocorreu o maior número de ocupações de terra e famílias em ocupações, com 856 ocupações e a participação de 113.909 famílias em ocupações. O aumento das ocupações de terra e famílias em ocupações referia-se à intensa e crescente desaprovação dos movimentos camponeses em relação ao governo e sua incompetência na realização da reforma agrária. Neste ano identifica-se que a criação de assentamentos rurais diminuiu em relação ao ano de $1998^{33}$, portanto o aumento das ocupações de terra visavam aumentar a criação de assentamentos rurais. Visto que o número de ocupações apresentava-se em constante crescimento o governo tomou atitudes para conter $\mathrm{o}$ número de conflitos na luta pela terra e também garantir a proteção da propriedade privada que era ameaçada pelas atuações dos movimentos ${ }^{34}$.

Assim, as medidas do governo centravam fogo nas ocupações de terra e visavam a contensão das atuações dos movimentos camponeses. De acordo com Stedile e Fernandes (1999) o principal objetivo do governo era a desmoralização de MST e a criminalização da luta pela terra (Fernandes, 2008). Estas medidas resultaram em uma queda do número de ocupações de terra $(39,36 \%)$ e famílias em ocupações $(28,32 \%)$ no ano de 2000. Na obra "Reforma Agrária: $O$ impossível diálogo"35 de José de Souza Martins, é evidente a perspectiva da falta de diálogo entre o MST, a CPT e o Governo.

Em 2001, o governo aprovou a medida provisória 2109-52 que criminalizava as ocupações de terra. A medida também foi uma estratégia de dominação e submissão à lógica da acumulação de capital. Visto que, as ocupações têm papel fundamental na luta pela terra e que é uma das principais práticas dos movimentos, a atitude do governo foi de intensa repreensão, pois atacava a principal ação contestativa, orgânica e estruturante dos movimentos, nocauteando-os temporariamente.

Esta ação foi uma medida de contenção territorial, pois o principal objetivo do governo era assegurar a posse da propriedade privada, se demonstrar dominante perante a opinião pública, fortalecer o isolamento dos movimentos, frear as ocupações e assegurar o modelo de desenvolvimento territorial neoliberal. A via de tornar essa medida eficiente era atacar a principal intenção dos sem-terra. Para isso a medida previa que o integrante que realizasse uma ocupação perderia direito ao acesso a terra através da reforma agrária e a fazenda ocupada não seria passível de reforma agrária durante o período de dois anos. Assim, a medida criou a imagem de uma inversão de ganhos e, portanto, as ocupações de terras que historicamente possibilitaram o acesso à terra agora teria efeito contrario e inviabilizaria o seu acesso ${ }^{36}$. Os reflexos desta medida foi uma súbita redução das ocupações de terra. Do ano de 2000 em relação ao ano de 1999 as ocupações diminuíram em 39,36\% e famílias em ocupações em $28,32 \%$ e do ano de 2000 em relação ao ano de 2001 houve redução de 47,39\% das ocupações de terra e 44,96\% das famílias em ocupação.

Ao compararmos os dados do ano de 1999 com os dados do ano de 2002 é evidente a redução significativa causada pela medida provisória, com diminuição de $68,68 \%$ das ocupações e $64,74 \%$ das famílias em ocupações. No entanto, a medida durou apenas até

\footnotetext{
${ }^{33}$ Ver Relatório DATALUTA 2010

34 Também, neste ano, criou-se o MDA - Ministério do Desenvolvimento Agrário, que tem por competência promover a agricultura familiar, porém, a reforma agrária continuou em passos lentos.

${ }^{35}$ Esta obra é um dos exemplos mais claros de ataque feito ao MST na academia, assim corroborando as tentativas do governo FHC em realizar o isolamento e a propaganda contra o movimento.

36 Essa medida corroborou a concepção das ocupações de terra como uma ação obstaculosa ao desenvolvimento.
} 
o ano de 2002. Outro elemento responsável pelo baixo número de ocupações e famílias em ocupações neste ano foi o processo eleitoral. A eleição do Presidente Lula contou diretamente com o apoio dos movimentos para a sua campanha, além de que o seu histórico de vínculo e representação da classe trabalhadora metalúrgica contribuiu para sua popularidade. A esperança de mudanças e o discurso de compromisso para com a classe trabalhadora foi uma das marcas durante a campanha, ou seja, havia clara expectativa de que o Presidente Lula traria benefícios para a classe trabalhadora rural e urbana.

No ano de 2002 ocorreu uma mudança significativa na conjuntura política. Depois de anos de tentativas fracassadas, Luís Inácio Lula da Silva conseguiu se eleger, trazendo consigo a esperança de transformação e avanços para a reforma agrária. Sua história de luta corroborava a expectativa de melhoria para os movimentos camponeses, de que a reforma agrária poderia sair do papel e que seria possível ampliar a luta pela reforma agrária. Para o MST, desde 1989, Lula simbolizava uma expectativa de mudança:

Parece folclórico, mas é simbólico, o que demonstra o quanto estávamos convencidos de que a vitória do Lula representaria a possibilidade de massificar a luta pela reforma agrária no Brasil. (Stedile e Fernandes, 1999. p.69).

Sua trajetória de luta e defesa pelos direitos dos trabalhadores e sua boa relação com os sindicatos e movimentos sociais serviu, sobretudo, para conseguir apoio no processo eleitoral em 2002. A luta pela terra sofria seu maior refluxo desde o governo Collor. As investidas do governo FHC reprimiram as ações dos movimentos camponeses e os mesmos vislumbravam a eleição de Lula como uma alternativa para o seu isolamento e a realização massiva da reforma agrária. Portanto, o processo eleitoral contou com o apoio legitimo dos movimentos camponeses. Outra importante mudança foi a proximidade com a CPT e o MST como destaca Fernandes:

Com a vitória do governo Lula, os movimentos camponeses participaram nas indicações de nomes para cargos de segundo escalão do governo Lula. O MST e a CPT tiveram forte influência na nomeação de vários cargos no Instituto Nacional de Colonização e Reforma Agrária (INCRA), inclusive indicando para presidente o geógrafo Marcelo Resende, que trabalhara no Instituto de Terras do Estado de Minas Gerais, durante a gestão do então governador Itamar Franco. A CONTAG também indicou alguns nomes para o Ministério do Desenvolvimento Agrário. (Fernandes, 2003, p. 37).

O diferencial do governo Lula foi a proximidade com os movimentos camponeses. A medida provisória que impactou na luta pela terra em 2001 e 2002 reduzindo o número de ocupações de terras e judiciarizando-as foi aos poucos deixada de lado. Em 2003, no primeiro ano de mandato do governo, as ocupações voltaram a crescer $(100,7 \%)$ assim como o número de famílias em ocupações de terra (124,20\%). Algumas ações do governo Lula sinalizavam que a luta pela terra teria avanços e a expectativa era de que no governo Lula se realizasse uma reforma agrária massiva com a criação de muitos assentamentos e subsídios para a agricultura familiar/camponesa. 
Ainda em 2003, uma equipe organizada por Plínio de Arruda Sampaio apresentou para o governo Lula uma proposta de II PNRA - Plano Nacional de Reforma Agrária que reconhecia a questão agrária em sua essência e como produto de um processo histórico no Brasil. O plano proposto por Sampaio (2003) visava atacar as distorções na estrutura fundiária diretamente, sobretudo através das desapropriações. Sua meta era assentar 1 milhão de trabalhadores pobres no campo com área suficiente para lhe possibilitar uma vida digna. Era evidente que o plano colocava em cheque os interesses da capital no campo e representava um risco por fortalecer e realizar as políticas de reforma agrária e sinalizar esperança aos movimentos sociais no campo.

Contudo, apesar das benesses para a reforma agrária e luta pela e na terra, a história não tomou esse rumo. Pelo fato do plano reconhecer a questão agrária como um problema estrutural e visar atacar a raiz do problema ele se tornou uma ameaça aos interesses do capital e, portanto, foi descartado. Em novembro de 2003 foi proposto pelo MDA e sancionado pelo presidente Lula o II PNRA - Plano Nacional de Reforma Agrária, que dentre vários objetivos visava garantir o acesso à terra, viabilizar condições para produção, geração de renda e assegurar os direitos básicos como saúde, educação, etc. O destaque deste II PNRA relacionava-se às políticas de assentamentos rurais, visando assentar 400 mil famílias, e a regularização fundiária, objetivando regularizar 500 mil famílias (Brasil, 2003). O II PNRA elaborado pelo MDA em comparação II PNRA elaborado por Sampaio (2003) tinham objetivos mais tímidos e menos radicais. A questão agrária e a luta pela terra não tinha tamanha importância quanto para Sampaio (2003) e as políticas de reforma agrária continuaram seguindo as tendências compensatórias que o governo FHC manteve e não visavam atingir a estrutura do problema.

No ano seguinte, 2004, com o desapontamento causado pela aprovação do II PNRA e declarações de Lula de que a reforma agrária não se faria na marra, as ocupações continuaram a crescer. Do ano de 2003 para 2004 as ocupações de terra aumentaram em $22,59 \%$ e as famílias em ocupações de terra alcançaram o segundo maior registro com 111.447 famílias e um crescimento de $23,81 \%$. Este aumento demonstra o desapontamento dos movimentos perante o governo.

No entanto, houveram mudanças significativas entre o governo FHC e o Governo Lula. No governo Lula recuperou-se o diálogo, reconhecimento e aumentou a proximidade com os movimentos. A estratégia de trazer alguns sindicatos, lideranças e movimentos sociais para o governo facilitava uma flexibilização do enfrentamento por meio de uma cooptação travestida em diálogo e "participação". Assim, através destas estratégias, garantiria o discurso do diálogo e da proximidade enquanto o agronegócio se fortalecia. Outra parte importante neste processo é que, de acordo com Fernandes (2003), os cargos oferecidos eram de segundo escalão, portanto subalternos ao governo Lula. Este fato também implicava na possível perda da autonomia dos movimentos, visto a relação de hierarquia com o governo. Esta é uma contradição significativa da postura de Lula em relação aos movimentos camponeses que o diferencia da política do governo FHC. No governo FHC tentou-se neutralizar os movimentos através do isolamento enquanto no governo Lula tentou-se neutralizar os movimentos através da proximidade e do diálogo.

Contudo, a desaprovação dos movimentos perante o governo Lula deve-se à inúmeras contradições, como: a histórica defesa pela reforma agrária e a sua não realização; incentivo ao avanço e a projeção da economia nacional com base no agronegócio; a 
realização de políticas paliativas e compensatórias ao invés de combater os problemas atacando a sua estrutura; seguir a tendência neoliberal de integração da agricultura familiar ao mercado e a realização da reforma agrária de mercado através das políticas do Banco Munidal; etc. Dentre elas destaca-se o fato de que Lula em seus dois mandatos criou 2.854 assentamentos e assentado 276.384 famílias enquanto durante os dois mandatos o governo FHC criou 3.947 assentamentos e assentou 394.287 famílias, ou seja, para um governo que se elegeu e re-elegeu com o discurso de atender a classe trabalhadores e combater a desigualdade e miséria criar 38,29\% assentamentos e assentar $42,65 \%$ famílias $^{37}$ a menos que o governo de de FHC, que assumiu uma postura de isolamento e defesa do neoliberalismo, e não cumprir com a meta de assentar as 400 mil famílias conforme previa o II PNRA, representando uma contraditoridade significativa entre discurso e prática.

Essa realidade demonstrouque apesar do compromisso entre o presidente Lula e os movimentos camponeses, a reforma agrária não foi tratada como prioridade pois em seus dois mandatos continuou a empregar o projeto neoliberal. No entanto, em seu governo surgiram novos elementos muito significativos para as ocupações de terras e que alteraram a dinâmica da luta pela terra, contribuindo para o refluxo e novas formas de luta.

\section{NOVOS ELEMENTOS DA LUTA PELA TERRA: ELEMENTOS PARA SE PENSAR E ANALISAR}

Nos últimos anos novos elementos surgiram na luta pela terra alterando sua dinâmica e criando novas formas, objetivos e significados para se ocupar a terra. Nosso desafio é levantar algumas das mudanças na luta pela terra e quais as diferentes entre as ocupações de terras na década passada em relação à atualidade. Para pensarmos e reconhecermos os novos elementos da luta pela terra que alteraram a dinâmica das ocupações de terra, um bom caminho é termos como referência os antigos aspectos, elementos e formas de se realizar a luta e as ocupações de terra. Fernandes (1994, 2000) e Feliciano (2002) são referências importantes para pensar e identificar as principais características das ocupações de terras e termos como parâmetro para reconhecer as mudança.

Parte importante que diferencia a luta pela terra da atualidade em relação à década passada refere-se aos espaços de socialização política. Neste sentido, Fernandes (1994, 2000) realiza uma discussão importante acerca dos espaços de socialização política, conceito primeiramente consolidado por Grzybowski (1987), e toma como referência as CEBs - Comunidades Eclesiais de Base como espaço de socialização política, visto sua importância para a realização das ocupações de terra e organização da luta pela terra. Assim, os espaços de socialização política possibilitavam avançar em diferentes sentidos, como: na organização da luta pela terra melhorando, elaborando e viabilizando o intercâmbio de novas práticas e formas de luta, resistência e de experiências; ampliando o sentido da luta pela terra; inserindo ainda mais a sociedade na luta; e avançando no processo de conscientização e formação política visando capacitar os militantes para o reconhecimento das conflitualidades e tornar as lutas ainda mais eficientes.

\footnotetext{
${ }^{37}$ Fonte: Dataluta, 2010.
} 
Além destes processos e objetivos, Fernandes (1994) destaca também o caráter coletivo da luta e como estes espaços possibilitaram o avanço da luta:

Para analisar essas diferentes formas, procuramos destacar, no processo de formação do MST, o espaço de socialização política e seu dimensionamento construídos pela práxis a partir da elaboração dos fatores objetivos e subjetivos, que contribuíram efetivamente para a conscientização dos trabalhadores, enquanto sujeito coletivo, e conseqüentemente, para a criação de uma identidade social e política, o que possibilitou o avanço da luta. (FERNANDES, 1994. p. 117).

Os espaços de socialização política antecediam os acampamentos e as ocupações de terras, pois eram onde a maioria das ocupações eram planejadas e organizadas ${ }^{38}$, e muitas vezes viabilizavam ou se originavam através de trabalhos de base ${ }^{39}$. Posteriormente, os acampamentos se tornavam também espaços de socialização política onde eram planejadas outras ações, como: ocupações de terra, marchas, manifestações, etc. Outro aspecto significante a ser considerado e relevado é da ocupação como forma de recriação do campesinato, ou seja, a ocupação como uma importante forma de acesso à terra (Fernandes, 2000). Assim, as ocupações de terra visam emergir situações, trazer à tona problemáticas, enfrentar o Estado, combater o latifúndio e o processo de exploração e expropriação intensificado pelo avanço do capitalismo no campo, tudo isso para poder, criar, recriar e garantir a existência e resistência do campesinato no campo. Portanto, a ocupação é uma conflitualidade gerada pelo avanço do capitalismo e que contraditoriamente visa o destruir através da recriação do campesinato.

$\mathrm{Na}$ atualidade, alguns elementos persistem. Contudo, tomaram novas proporções e direcionamentos. As ocupações além de atacar o Estado e o latifúndio passaram também a atacar o agronegócio, pois para os movimentos este representa uma ameaça travestida para a sociedade na imagem da modernidade e desenvolvimento no campo. Os espaços de socialização política como as CEBs não existem mais, ou seja, na atualidade o processo de organização da luta tomou uma nova dinâmica. A grosso modo, inicia-se nos trabalhos de base e os novos integrantes são direcionados para os acampamentos e, então, dos acampamentos saem para as ocupações de terras. Portanto, alguns espaços de socialização política foram extintos e outros enfraquecidos por conseqüente despolitização dos militantes, como os acampamentos.

Além destas mudanças, novos elementos surgiram e alteraram a dinâmica da luta pela terra e, conseqüentemente, das ocupações de terra, estes são:

1-) o programa Bolsa Família criado pela Lei $\mathrm{n}^{\mathrm{o}}$ 10.836, de 09 de janeiro de 2004 e o Decreto $\mathrm{n}^{\circ} 5.209$, de 17 de setembro de 2004, visando combater a pobreza e promover a redistribuição de renda ${ }^{40}$;

2-) O processo de dissensão dos movimentos nos movimentos sociais criou novas formas de se fazer a luta e novos movimentos camponeses com vinculações político-

\footnotetext{
${ }^{38}$ Estes espaços eram construídos e controlados pelos militantes envolvidos e solidários à luta.

39 As reuniões realizadas nos trabalhos de base são espaços geradores de sujeitos construindo suas próprias existências. (p. 284)

${ }^{40}$ O Bolsa família é uma política pública compensatória que ao mesmo tempo que pelos seus requisitos de beneficiário tem impactado com o esvaziamento dos acampamentos, de uma parcela da população que desiste da luta e retorna para a cidade, também tem viabilizado a permanência garantindo condições mínimas no acampamento.
} 
ideológicas diferenciadas, mudando o caráter massivo da sua luta (Sobreiro Filho, 2011);

3-) o aumento da demora para se conquistar a terra devido à redução de criação de assentamentos rurais que implica na desistência de militantes na luta e resistência nos acampamentos sob condições precárias de vida;

4-) o surgimento e fortalecimento do agronegócio, que é visto pela sociedade e propagandeado pelo governo como a "salvação da lavoura" e sinônimo de desenvolvimento (Thomaz Junior, 2007), sinalizando uma ameaça para os movimentos camponeses visto que têm que enfrentar o Estado e o Capital juntos;

5-) o descenso no número de acampados e de barracos, pois atualmente uma parte dos acampados vivem na cidade durante a semana e nos fins de semana vão para o acampamento $^{41}$;

6-) significativa redução no número de famílias em ocupações e barracos em ocupações, pois devido aos descenso têm se tornado uma estratégia dos movimentos para conseguir realizar várias ocupações;

7-) novas formas de criminalização e perseguição política, pois diferentemente das formas de repressão realizadas pelas "próprias mãos" ou "na base da bala" atualmente a principal via de para reprimi-las tem sido através da esfera jurídica;

8-) o avanço da reforma agrária de mercado, ou seja, a perspectiva da realização da reforma agrária através do mercado, que leva alguns acampados a comprar o seu lote e desistir da luta pela terra; etc.

Diante desta conflituosa realidade e gama de elementos e processos que compreendem a questão agrária brasileira e atingem a luta pela terra, surge como desafio importante tentar entendê-los em um quadro único e dialético. Tomar nota, desvendar essa realidade e compreendê-la nos parece instigante, sobretudo, porque alguns dos elementos e processos que tem asseverado a luta pela terra na atualidade se originaram no governo FHC, mas, sobretudo, os mais impactantes na atualidade se formaram e fortaleceram no governo Lula. Por fim, um bom caminho para compreendermos estas diferenças em sua totalidade é tomarmos como referência as variações na conjuntura política através do enfoque da conflitualidade travada entre os movimentos camponeses, o Estado e o Agronegócio/capital, e tendo o espaço/territórios como parâmetro para a análise geográfica.

\section{CONSIDERAÇÕES FINAIS}

Pensar uma leitura geográfica da conflitualidade é ter que refletir tanto a relação homem-homem quanto a relação homem-espaço e produção e reprodução de ambos tendo como ponto de partida o fato de que todas as relações de poder que ocorrem no espaço pressupõem conflitualidade. Portanto é eminente que em uma análise geográfica que se dispõe à discussão do território o fato de que a conflitualidade está em todas as relações. Também é fato que a conflitualidade não se constitui em uma relação obstáculosa. Assim sendo, caminhamos no sentido de contribuir para a construção de uma consciência onde a conflitualidade tenha papel importante no desenvolvimento da sociedade (evidenciando seu caráter ontológico), no alcance da democracia, nas lutas emancipatórias, etc.

\footnotetext{
${ }^{41}$ Em alguns movimentos os acampados que vivem neste processo pendular são denominados de "andorinhas".
} 
No transcorrer das transformações políticas e muitas vezes as ocupações de terra e outras ações dos movimentos camponeses foram interpretadas como entraves e ameaças para o desenvolvimento. Muitas foram as tentativas de neutralizar e diversas as estratégias de reprimir os movimentos. O capital e o Estado tentaram e tentam conter as ações de enfrentamento criando, recriando e inovando formas de desarticulação, cooptação, integração e subordinação dos movimentos camponeses. Contudo, mesmo diante inúmeras dificuldades os movimentos camponeses resistiram em suas lutas. Diante de um quadro geral ficam as dúvidas acerca da perspectiva da luta pela terra perante à realidade de novos elementos na atualidade.

\section{REFERENCIAL BIBLIOGRÁFICO}

BRASIL, Ministério do Desenvolvimento Agrário. II Plano Nacional de Reforma Agrária. Brasília, 2003.

COLETTI, C. Neoliberalismo e burguesia agrária no Brasil. Revista Lutas e Resistências, 2006, Londrina, $\mathrm{n}^{\mathrm{o}} 1$.

FELÍCIO, M. J. A conflitualidade dos paradigmas da questão agrária e do capitalismo agrário a partir dos conceitos de agricultor familiar e de camponês. Campo-Território: Revista de Geografia Agrária, 2006, vol. 1, no 2, p. 14-30.

FELICIANO, C. A. A Geografia dos Assentamentos Rurais no Brasil: O MST e MAST no Pontal do Paranapanema/SP. $131 \mathrm{f}$. Monografia (curso de Geografia). São Paulo: Universidade de São Paulo, Faculdade de Filosofia, Letras e Ciências Humanas, 1999.

FELICIANO, C. A. Movimento Camponês rebelde: a reforma agrária no Brasil. São Paulo: Contexto, 2006.

FERNANDES, B. M. A formação do MST no Brasil. Petrópolis: Vozes, 2000.

FERNANDES, B. M. Espacialização e territorialização da luta pela terra: a formação do MST - Movimento dos Trabalhadores Rurais Sem Terra no Estado de São Paulo. 218 f. Dissertação (Mestrado). São Paulo: Universidade de São Paulo, Faculdade de Filosofia, Letras e Ciências Humanas, 1994.

FERNANDES, B. M. Movimentos socioterritoriais e movimentos socioespaciais. Observatório Social de América Latina, 2005, vol. 16. Buenos Aires: CLACSO, p. 273-284.

FERNANDES, B. M. Questão Agrária: conflitualidade e desenvolvimento territorial. In: A. MÂRCIO BUAINAIN (Ed.). Luta pela Terra: Reforma Agrária e Gestão de Conflitos no Brasil. Editora Unicamp: Campinas, 2009.

FERNANDES, B. M. Relatório DATALUTA 2010. Presidente Prudente: NERA, 2008.

FERNANDES, B. M. Sobre a tipologia de territórios. In: A. M. SAQUET e E. S. SPOSITO (Ed.). Territórios e territorialidades: teorias, processos e conflitos. São Paulo: Expressão Popular, 2009, p. 197-215. 
GRZYBOWSKI C. Caminhos e descaminhos dos movimentos sociais no campo. Petrópolis: FASE/Vozes, 1987.

HAESBAERTT, R. O mito da desterritorialização. Rio de Janeiro: Bertrand Brasil, 2004.

MARTINS, J. S. Os camponeses e a política no Brasil. Petrópolis: Vozes, 1981.

MARTINS, J. S. Reforma Agrária: O impossível diálogo. São Paulo: Hucitec, 2000.

PEDON, N. R. Movimentos Socioterritoriais: Uma Contribuição Conceitual à Pesquisa Geográfica. 235 f. Tese (Doutorado). Presidente Prudente: Universidade Estadual Paulista Júlio de Mesquita Filho, 2009.

RAFFESTIN, C. Por uma Geografia do Poder. São Paulo: Ática, 1993.

SAMPAIO, P. de A.(Org). Proposta de Plano Nacional de Reforma Agrária. Brasília, 2003.

SAQUET, M. A. Por uma abordagem territorial. In. A. M. SAQUET e E. S. SPOSITO. Territórios e territorialidades: teorias, processos e conflitos. São Paulo: Expressão Popular, 2009, p. 197-215.

SEARLE, J. R. Intencionalidade. São Paulo: Martins Fontes, 1995.

SOBREIRO FILHO, J. Os MST's do Pontal do Paranapanema: dissensão na formação dos movimentos camponeses. Relatório de pesquisa. FAPESP, 2011. $<\underline{\text { http://www4.fct.unesp.br/nera/projetos/relatorio_nino2.pdf }>\text {. }}$

SOUZA, M. L. Território" da divergência (e da confusão): em torno das imprecisas fronteiras de um conceito fundamental. In. A. M. SAQUET e E. S. SPOSITO. Territórios e territorialidades: teorias, processos e conflitos. São Paulo: Expressão Popular, 2009, p. 197-215.

STEDILE, J. P. e FERNANDES, B. M. Brava Gente: a trajetória do MST e a luta pela terra no Brasil. São Paulo: Perseu Abramo, 1999.

THOMAZ JUNIOR, A. Não há nada de Novo sob o Sol num Mundo de Heróis! (A Civilização da Barbárie na Agroindústria Canavieira). Revista Pegada, 2007, vol. 8, n $^{\circ}$ 2, p. $5-25$. 